Article

\title{
Analysis and Prediction of Corrosion of Refractory Materials by Potassium during Biomass Combustion-Thermodynamic Study
}

\author{
Ying Zhao ${ }^{1, *}$, Guishi Cheng ${ }^{1}$, Fei Long ${ }^{2}$, Lu Liu ${ }^{1}$, Changqing Dong ${ }^{1}$, Xiaoqiang Wang ${ }^{1}$ \\ and Jin Zhao ${ }^{3}$ \\ 1 National Engineering Laboratory for Biomass Power Generation Equipment, School of the Renewable \\ Energy, North China Electric Power University, Beijing 102206, China; 51101890@ncepu.edu.cn (G.C.); \\ 51102247@ncepu.edu.cn (L.L.); cqdong@ncepu.edu.cn (C.D.); energy@ncepu.edu.cn (X.W.) \\ 2 Department of Mechanical and Material Engineering, Queen's University, Kingston, ON K7L 3N6, Canada; \\ long.fei@queensu.ca \\ 3 State Grid Energy Conservation Services CO., Ltd., Beijing 100056, China; zhaojin@sgecs.sgcc.com.cn \\ * Correspondence: zhaoying1989@ncepu.edu.cn; Tel.: +86-010-6177-2060
}

Received: 9 November 2018; Accepted: 15 December 2018; Published: 18 December 2018

\begin{abstract}
As a kind of renewable resource, biomass has been used more and more widely, but the potassium contained in biomass can cause corrosion of the refractory. For a better understanding of corrosion thermodynamic mechanisms, the five components of common refractory materials (magnesium chrome spinel $\mathrm{MgO} \cdot \mathrm{Cr}_{2} \mathrm{O}_{3}$, magnesium aluminum spinel $\mathrm{MgO} \cdot \mathrm{Al}_{2} \mathrm{O}_{3}, \mathrm{Al}_{2} \mathrm{O}_{3}, \mathrm{MgO}$, and $\left.\mathrm{Cr}_{2} \mathrm{O}_{3}\right)$ with potassium salts $\left(\mathrm{K}_{2} \mathrm{CO}_{3}, \mathrm{~K}_{2} \mathrm{SO}_{4}\right.$, and $\left.\mathrm{KCl}\right)$ under high-temperature were studied by using the FactSage ${ }^{\mathrm{TM}} 7.0$ software. Thermodynamic calculation results indicate that $\mathrm{MgO}$ is the best corrosion resistance of the five components of refractory materials. Based on the obtained results, the corrosion experiments in the laboratory were carried out (muffle furnace or high-temperature tube furnace) for corrosion reaction of $\mathrm{KCl}$ and $\mathrm{MgO}$. The chemical compositions of the corroded samples were analyzed by X-ray diffraction (XRD). Under laboratory conditions $\left(600-1200{ }^{\circ} \mathrm{C}\right)$, no corrosion products have been observed in the high-temperature corrosion experiments. The result indicates that to prevent the corrosion processes, refractories should contain as much $\mathrm{MgO}$ as possible.
\end{abstract}

Keywords: corrosion; refractory material; thermodynamic; potassium salt

\section{Introduction}

The total amount of biomass accumulated in the world every year is equivalent to 10 times of the total energy consumption of the year. Biomass is the fourth energy after coal, oil, and natural gas, and contributes $14 \%$ to the world's primary energy consumption [1,2]. Biomass has the characteristic of near-zero carbon dioxide emissions. Therefore, the development and utilization of biomass energy is an important way to optimize energy structure, alleviate the contradiction between energy supply and demand, protect the environment and reduce greenhouse gas emissions. As one of the important renewable energy sources, biomass energy occupies an important position in energy system [3]. In recent years, China has accelerated the adjustment of its energy structure, actively promoted the development and utilization of biomass energy, and biomass power generation has been flourishing. In coal $\mathrm{K}$ primarily exists in the format of feldspar $\left(\mathrm{K}_{2} \mathrm{O} \cdot \mathrm{Al}_{2} \mathrm{O}_{3} \cdot 6 \mathrm{SiO}_{2}\right)$ while the content of activated $\mathrm{K}$ species (e.g., $\mathrm{K}_{2} \mathrm{SO}_{4}, \mathrm{KCl}, \mathrm{K}_{2} \mathrm{CO}_{3}$ ) is negligible [4,5]. However, it is very different in biomass. As it has a very high ratio of oxygen, a part of potassium is combined with a strong oxygen-containing functional group, and some other parts are present in the inner mineral or combined with the organic functional group. Since the potassium content of biomass is much higher than that of coal, high 
levels of potassium compounds, especially potassium chloride, can cause severe corrosion of boilers during combustion.

Many studies have focused on the mechanism of potassium release during biomass combustion/gasification/pyrolysis [6-9]. J. M. Johansen et al. [10] reported that $\mathrm{Cl}$ was the main facilitator for $\mathrm{K}$ release through sublimation of $\mathrm{KCl}$ at the reaction temperature above $700-800{ }^{\circ} \mathrm{C}$. $\mathrm{H}$. Kassman et al. [11] also reported that $\mathrm{Cl}$ could facilitate the release of $\mathrm{K}$ by the formation of $\mathrm{KCl}(\mathrm{g})$ in the biomass combustion at high temperatures. In addition, the ash agglomeration behavior caused by potassium during biomass combustion/pyrolysis/gasification is also the focus of researchers [12-15]. $\mathrm{H}$. Zhan et al. [16] suggested that coal ash is a potential additive for not only fixing potassium, but also increasing the temperatures of biomass ash fusion. The effect of potassium compounds on the corrosion of equipment in biomass is mainly focused on the superheater metal materials [17-20]. Nevertheless, up to now, only a few researches have focused on the mechanism of corrosion of refractory by biomass ash [21]. It is very limited that there are thermodynamic studies on the corrosion of refractory by active potassium in biomass combustion are limited.

Since the corrosion behavior of potassium on refractories during biomass combustion is greatly affected by temperature and potassium salt type, this study mainly investigates different combustion temperatures $\left(600,700,800,900,1000,1100\right.$, and $\left.1200{ }^{\circ} \mathrm{C}\right)$. Different kinds of active potassium $\left(\mathrm{K}_{2} \mathrm{CO}_{3}\right.$, $\mathrm{K}_{2} \mathrm{SO}_{4}$, and $\mathrm{KCl}$ ) corrode five components of common refractory materials (magnesium chrome spinel $\mathrm{MgO} \cdot \mathrm{Cr}_{2} \mathrm{O}_{3}$, magnesium aluminum spinel $\mathrm{MgO} \cdot \mathrm{Al}_{2} \mathrm{O}_{3}, \mathrm{Al}_{2} \mathrm{O}_{3}, \mathrm{MgO}$, and $\mathrm{Cr}_{2} \mathrm{O}_{3}$ ). The FactSage ${ }^{\mathrm{TM}} 7.0$ software was used to simulate the interaction of the five components with three kinds of potassium salts based on the established calculation model and predict the phase formation when thermodynamic equilibrium was reached. The Gibbs free energy of each reaction under different conditions are calculated by using the FactSage $\mathrm{T}^{\mathrm{TM}} 7.0$ software. We systematically analyzed the possibility of reacting five components of common refractory materials with three kinds of potassium salts and the mineral phase of corrosion products. We obtained the direction and limit of reaction in the multi-reaction system of refractory by potassium corrosion process and the affection of corrosion by temperature and potassium salt type. The goal of this paper is to provide guidance for the selection and optimization of biomass boiler refractories.

\section{Thermodynamic Calculations}

Thermodynamic calculations were carried out using the version 7.0 of the FactSage ${ }^{\mathrm{TM}}$ software package (GTT Technologies, Aachen, Germany and Thermfact/CRCT, Montreal, QC, Canada), because it is one of the largest fully integrated databases in the field of chemical thermodynamics. FactSage ${ }^{\mathrm{TM}}$ 7.0 software contains several thermodynamic databases, including a database of FactPS (the FactSage ${ }^{\mathrm{TM}}$ 7.0 contains 6872 kinds of compounds) evaluation and optimization of hundreds of metal solutions, oxide liquid phase and solid phase solutions, hydrazine, molten salt, aqueous solutions and other solution databases. The FactSage ${ }^{\mathrm{TM}}$ software is based on the system's minimum Gibbs free energy and provides information on the phases formed, their proportions and composition, the individual activities of each chemical component, and the thermodynamic properties of various compositions, pressures, and temperatures [22]. Therefore, FactSage ${ }^{\mathrm{TM}}$ software can conduct the thermodynamic calculation of the corrosion of refractory by potassium salt. In this study, the Equilib module was used which is adapted to multi-component systems like potassium compounds and refractory materials.

In this paper, three kinds of oxide components commonly used in refractories and two kinds of spinels synthesized by them are selected as research objects. The three oxides are $\mathrm{Al}_{2} \mathrm{O}_{3}, \mathrm{MgO}$, and $\mathrm{Cr}_{2} \mathrm{O}_{3}$, and the two spinels are $\mathrm{MgO} \cdot \mathrm{Cr}_{2} \mathrm{O}_{3}$ and $\mathrm{MgO} \cdot \mathrm{Al}_{2} \mathrm{O}_{3}$. In order to investigate the corrosion mechanism of potassium compounds on the five components of refractory materials, three potassium salts $\mathrm{K}_{2} \mathrm{CO}_{3}, \mathrm{~K}_{2} \mathrm{SO}_{4}$, and $\mathrm{KCl}$ were selected. This is because active potassium is present in the solid and gas phases in the form of these three potassium salts during biomass combustion.

$1 \mathrm{~mol}$ of the five components of refractory materials and three potassium salts were used as input data for the calculation. The Equilib module was used to calculate the change of Gibbs free energy 
in the corrosion of five components of refractory materials by three potassium salts. The trend of reaction was analyzed. The larger the negative value of Gibbs free energy, the greater the reaction trend. Moreover, corrosion products at different temperatures were obtained, and the chemical reaction equations that may occur during the corrosion process were inferred. All simulations were performed with temperatures varying from 600 to $1200{ }^{\circ} \mathrm{C}$ in steps of $100^{\circ} \mathrm{C}$ at $1 \mathrm{~atm}$ pressure.

\section{Thermodynamic Experimental Procedure}

A total of three sets of experiments were performed at different temperatures, 600, 1000, and $1200{ }^{\circ} \mathrm{C}$. The corrosion test at $600{ }^{\circ} \mathrm{C}$ is controlled by a control box type muffle furnace (GW-300C China Coal Research Institute, Beijing, China). Since the maximum temperature of the muffle furnace is less than $1000{ }^{\circ} \mathrm{C}$, the corrosion experiments at $1000{ }^{\circ} \mathrm{C}$ and $1200{ }^{\circ} \mathrm{C}$ were performed by high-temperature tube furnace (TF-1700C Beijing MeiCheng Scientific Instrument Co., Ltd., Beijing, China). Control box type resistance muffle furnace, with a double furnace ceramic fiber structure and a modular control system, can automatically raise temperature and maintain the constant temperature, and has accurate stable and reliable temperature control. The high-temperature tube furnace adopts a high-temperature corundum tube, and the temperature can be controlled by the temperature controller, which allows the temperature to vary between room temperature and $1700{ }^{\circ} \mathrm{C}$.

$\mathrm{KCl}$ and $\mathrm{MgO}$ samples (molar ratio of 1 ) were placed in muffle furnace or high-temperature tube furnace. After warming to a specified temperature, the furnace stayed in standby mode for $4 \mathrm{~h}$. When the experiment was completed and the tube furnace was cooled to room temperature, experiment reaction products were analyzed by XRD (Shimadzu, Kyoto, Japan) and Jade 5.0 software (Materials Data Ltd., Livermore, CA, USA).

\section{Results and Discussion}

\subsection{Corrosion Reaction of $\mathrm{K}_{2} \mathrm{CO}_{3}$ and the Five Components of Refractory Materials}

As can be seen from Figure 1, in the range of 600 to $1200{ }^{\circ} \mathrm{C}$, the Gibbs free energy of the reactions between each of the five components of refractory materials and $\mathrm{K}_{2} \mathrm{CO}_{3}$ are all negative. The Gibbs free energy becomes more negative gradually with the increasing of the temperature which indicates that the higher the temperature, the greater the tendency of the refractory to be corroded by $\mathrm{K}_{2} \mathrm{CO}_{3}$.

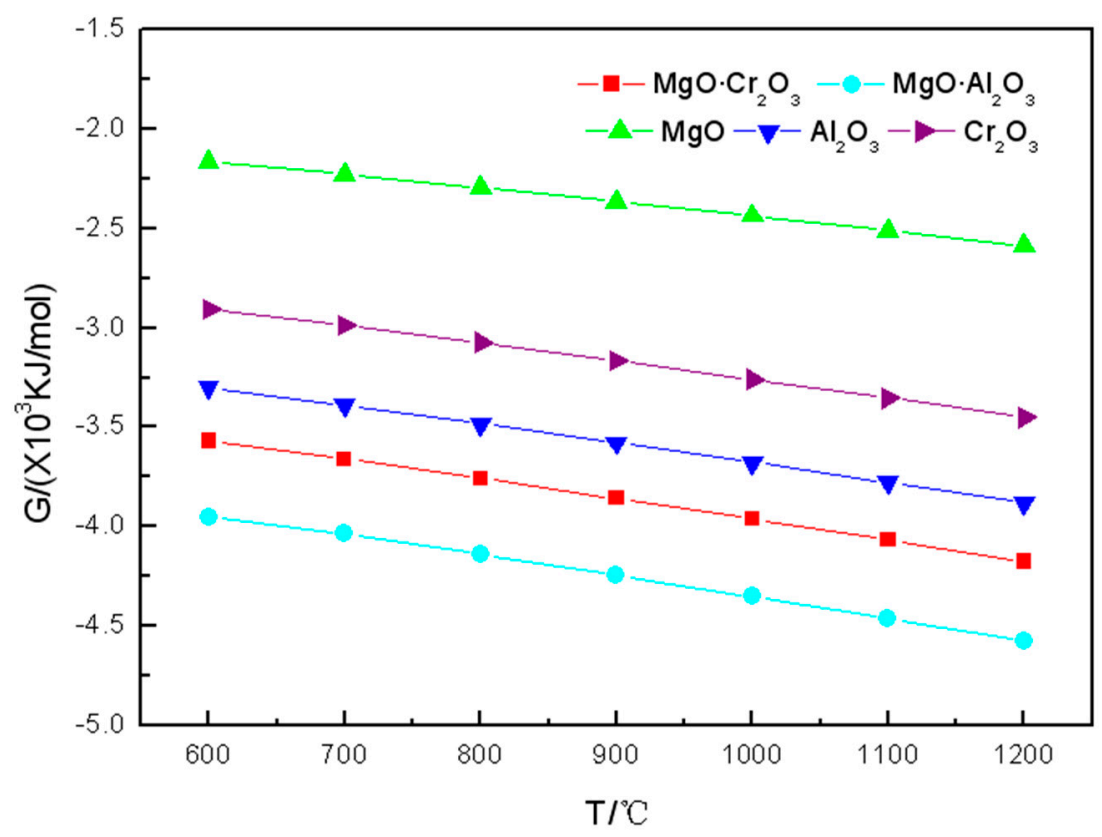

Figure 1. Gibbs free energy of the reaction between $\mathrm{K}_{2} \mathrm{CO}_{3}$ and the five components of refractory materials in the $600-1200{ }^{\circ} \mathrm{C}$ temperature range. 
Corrosion products and reaction equations of $\mathrm{K}_{2} \mathrm{CO}_{3}$ reacting with five components of refractory materials are shown in Table 1 . It can be seen from Table 1 that the two oxides $\left(\mathrm{Al}_{2} \mathrm{O}_{3}\right.$ and $\left.\mathrm{Cr}_{2} \mathrm{O}_{3}\right)$ and the two spinels are corroded by potassium carbonate at $600{ }^{\circ} \mathrm{C}$. The reactions in which $\mathrm{Cr}_{2} \mathrm{O}_{3}$ and $\mathrm{MgO} \cdot \mathrm{Cr}_{2} \mathrm{O}_{3}$ are corroded by $\mathrm{K}_{2} \mathrm{CO}_{3}$ at $600-1200{ }^{\circ} \mathrm{C}$ are

$$
\begin{gathered}
\mathrm{K}_{2} \mathrm{CO}_{3}+1 / 2 \mathrm{Cr}_{2} \mathrm{O}_{3}+3 / 4 \mathrm{O}_{2}=\mathrm{K}_{2} \mathrm{CrO}_{4}+\mathrm{CO}_{2} \\
\mathrm{~K}_{2} \mathrm{CO}_{3}+1 / 2 \mathrm{MgO} \cdot \mathrm{Cr}_{2} \mathrm{O}_{3}+3 / 4 \mathrm{O}_{2}=1 / 2 \mathrm{MgO}+\mathrm{K}_{2} \mathrm{CrO}_{4}+\mathrm{CO}_{2}
\end{gathered}
$$

The reaction product of $\mathrm{Al}_{2} \mathrm{O}_{3}$ and $\mathrm{MgO} \cdot \mathrm{Al}_{2} \mathrm{O}_{3}$ corroded by $\mathrm{K}_{2} \mathrm{CO}_{3}$ and the degree of reaction are related to temperature. At $600{ }^{\circ} \mathrm{C}, 0.3416 \mathrm{~mol}$ of $\mathrm{Al}_{2} \mathrm{O}_{3}$ is corroded by $\mathrm{K}_{2} \mathrm{CO}_{3}$ to form $\mathrm{K}_{2} \mathrm{Al}_{12} \mathrm{O}_{19}$ through reaction (3), and $0.6584 \mathrm{~mol}$ of $\mathrm{Al}_{2} \mathrm{O}_{3}$ is corroded by $\mathrm{K}_{2} \mathrm{CO}_{3}$ to form $\mathrm{KAlO}_{2}$ through reaction (4). At $700-1200{ }^{\circ} \mathrm{C}, \mathrm{Al}_{2} \mathrm{O}_{3}$ is corroded by $\mathrm{K}_{2} \mathrm{CO}_{3}$ through reaction (4), and $1 \mathrm{~mol}$ of $\mathrm{Al}_{2} \mathrm{O}_{3}$ is completely corroded to form 2 mol of $\mathrm{KAlO}_{2}$.

The two reactions in which $\mathrm{Al}_{2} \mathrm{O}_{3}$ is corroded by $\mathrm{K}_{2} \mathrm{CO}_{3}$ are

$$
\begin{gathered}
\mathrm{K}_{2} \mathrm{CO}_{3}+6 \mathrm{Al}_{2} \mathrm{O}_{3}=\mathrm{K}_{2} \mathrm{Al}_{12} \mathrm{O}_{19}+\mathrm{CO}_{2} \\
\mathrm{~K}_{2} \mathrm{CO}_{3}+\mathrm{Al}_{2} \mathrm{O}_{3}=2 \mathrm{KAlO}_{2}+\mathrm{CO}_{2}
\end{gathered}
$$

At $600{ }^{\circ} \mathrm{C}$, only $0.0608 \mathrm{~mol}$ of $\mathrm{MgO} \cdot \mathrm{Al}_{2} \mathrm{O}_{3}$ is corroded to form $\mathrm{KAlO}_{2}$ and $\mathrm{MgO}$, while at $700-1200{ }^{\circ} \mathrm{C}, 1 \mathrm{~mol}$ of $\mathrm{MgO} \cdot \mathrm{Al}_{2} \mathrm{O}_{3}$ is completely corroded, as described by reactions (5).

$$
\mathrm{K}_{2} \mathrm{CO}_{3}+\mathrm{MgO} \cdot \mathrm{Al}_{2} \mathrm{O}_{3}=2 \mathrm{KAlO}_{2}+\mathrm{MgO}+\mathrm{CO}_{2}
$$

Furthermore, it can be seen from the table that the amount of corrosion products in which $\mathrm{MgO}$ reacted with $\mathrm{K}_{2} \mathrm{CO}_{3}$ is less than $10^{-4}$ mol. However, it can be seen from Figure 1 that the Gibbs free energy of the reaction between $\mathrm{K}_{2} \mathrm{CO}_{3}$ and $\mathrm{MgO}$ is negative. This is because the calculation results of FactSage ${ }^{\mathrm{TM}} 7.0$ showed that $\mathrm{K}_{2} \mathrm{CO}_{3}$ will decompose at $600-1200{ }^{\circ} \mathrm{C}$ to produce $\mathrm{KO}_{2}, \mathrm{~K}_{2} \mathrm{O}_{2}$, and $\mathrm{K}_{2} \mathrm{O}$.

\begin{tabular}{|c|c|c|}
\hline \multirow{2}{*}{ Species } & \multicolumn{2}{|c|}{ Temperature $\left({ }^{\circ} \mathrm{C}\right)$} \\
\hline & 600 & $700-1200$ \\
\hline $\mathrm{Al}_{2} \mathrm{O}_{3}$ & $\begin{array}{c}1.3168 \mathrm{~mol} \mathrm{KAlO}_{2}, 0.0569 \mathrm{~mol} \mathrm{~K}{ }_{2} \mathrm{Al}_{12} \mathrm{O}_{19} \\
\text { Equations (3) and (4) }\end{array}$ & $\begin{array}{c}2 \text { mol } \mathrm{KAlO}_{2} \\
\text { Equation (4) }\end{array}$ \\
\hline $\mathrm{MgO}$ & \multicolumn{2}{|l|}{-} \\
\hline $\mathrm{Cr}_{2} \mathrm{O}_{3}$ & \multicolumn{2}{|l|}{$\begin{array}{c}1 \mathrm{~mol} \mathrm{~K}_{2} \mathrm{CrO}_{4} \\
\text { Equation (1) }\end{array}$} \\
\hline $\mathrm{MgO} \cdot \mathrm{Cr}_{2} \mathrm{O}_{3}$ & \multicolumn{2}{|c|}{$\begin{array}{c}1 \mathrm{~mol} \mathrm{~K}_{2} \mathrm{CrO}_{4}, 0.5 \mathrm{~mol} \mathrm{MgO} \\
\text { Equation (2) }\end{array}$} \\
\hline $\mathrm{MgO} \cdot \mathrm{Al}_{2} \mathrm{O}_{3}$ & $\begin{array}{c}0.1215 \mathrm{~mol} \mathrm{KAlO}_{2}, 0.0608 \mathrm{~mol} \mathrm{MgO} \\
\text { Equation (5) }\end{array}$ & $\begin{array}{c}2 \mathrm{~mol} \mathrm{KAlO}_{2}, 1 \mathrm{~mol} \mathrm{MgO} \\
\text { Equation (5) }\end{array}$ \\
\hline
\end{tabular}
This explains why the Gibbs free energy of $\mathrm{MgO}$ reacts with $\mathrm{K}_{2} \mathrm{CO}_{3}$ is negative. Therefore, $\mathrm{MgO}$ is the best corrosion resistance of the five components of refractory materials.

Table 1. Corrosion products and reaction equations of $\mathrm{K}_{2} \mathrm{CO}_{3}$ reacting with the five components of refractory materials.

\subsection{Corrosion Reaction of $\mathrm{K}_{2} \mathrm{SO}_{4}$ and the Five Components of Refractory Materials}

It can be seen from Figure 2 that the tendency of Gibbs free energy change of the five components of refractory materials reacted with $\mathrm{K}_{2} \mathrm{SO}_{4}$ in the range of 600 to $1200{ }^{\circ} \mathrm{C}$ is consistent with the one of reactions between the five components of refractory materials and $\mathrm{K}_{2} \mathrm{CO}_{3}$. Two spinels $\left(\mathrm{MgO} \cdot \mathrm{Cr}_{2} \mathrm{O}_{3}\right.$ 
and $\mathrm{MgO} \cdot \mathrm{Al}_{2} \mathrm{O}_{3}$ ) are more strongly corroded by $\mathrm{K}_{2} \mathrm{SO}_{4}$, while $\mathrm{MgO}$ has the least tendency to be corroded by $\mathrm{K}_{2} \mathrm{SO}_{4}$.

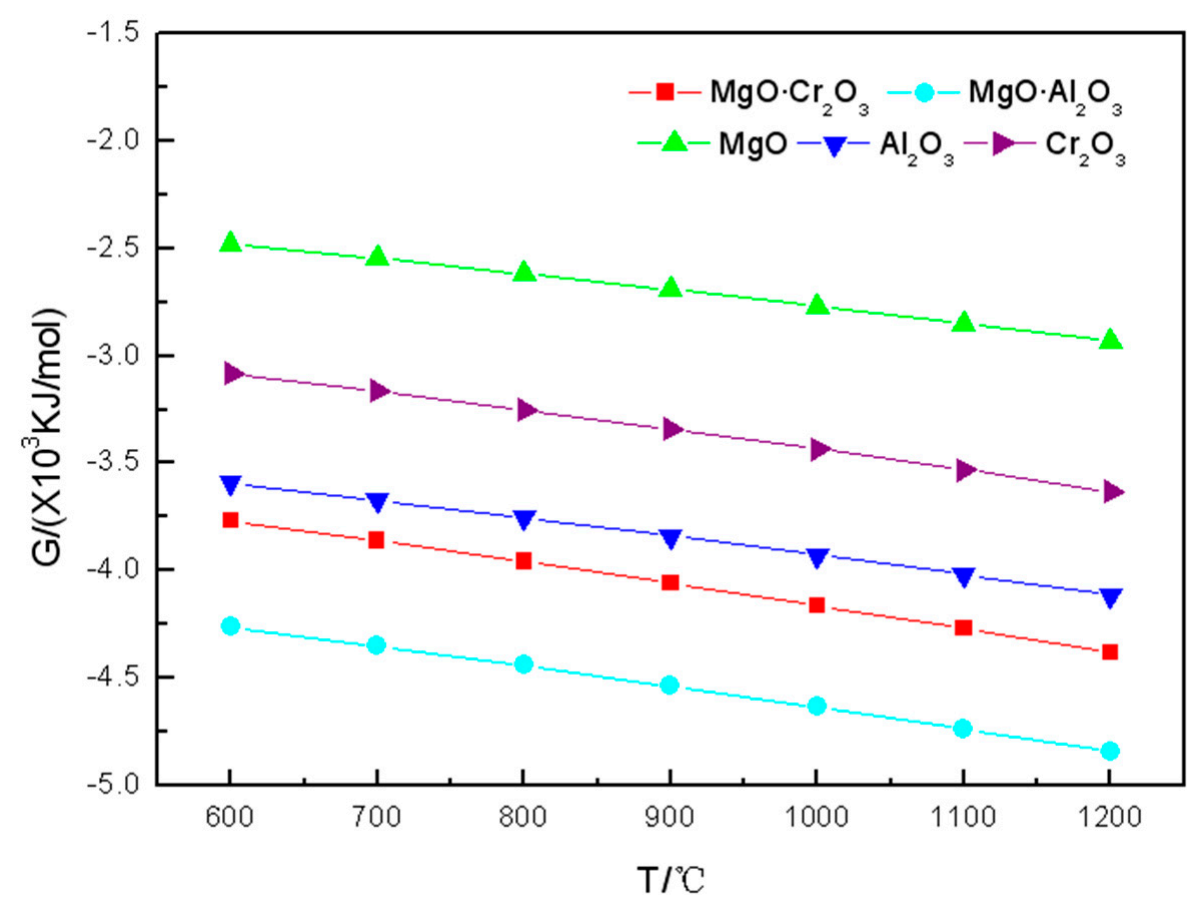

Figure 2. Gibbs free energy of the reaction between $\mathrm{K}_{2} \mathrm{SO}_{4}$ and the five components of refractory materials in the $600-1200{ }^{\circ} \mathrm{C}$ temperature range.

From Table 2, we can find that at $600-900{ }^{\circ} \mathrm{C}$, the five components of refractory materials are not corroded by $\mathrm{K}_{2} \mathrm{SO}_{4}$. However, when the temperature further increased to $1000{ }^{\circ} \mathrm{C}$, a small amount of $\mathrm{Cr}_{2} \mathrm{O}_{3}(0.0001 \mathrm{~mol})$ is corroded by $\mathrm{K}_{2} \mathrm{SO}_{4}$ to form $\mathrm{K}_{2} \mathrm{CrO}_{4}$. As the temperature increases, more $\mathrm{Cr}_{2} \mathrm{O}_{3}$ is corroded by $\mathrm{K}_{2} \mathrm{SO}_{4}$ through reactions (6)

$$
\mathrm{K}_{2} \mathrm{SO}_{4}+1 / 2 \mathrm{Cr}_{2} \mathrm{O}_{3}+3 / 4 \mathrm{O}_{2}=\mathrm{K}_{2} \mathrm{CrO}_{4}+\mathrm{SO}_{3}
$$

Similarly, when the temperature rises to $1100{ }^{\circ} \mathrm{C}, 0.004 \mathrm{~mol}$ of $\mathrm{Al}_{2} \mathrm{O}_{3}$ and $0.00005 \mathrm{~mol}$ of $\mathrm{MgO} \cdot \mathrm{Cr}_{2} \mathrm{O}_{3}$ are corroded by $\mathrm{K}_{2} \mathrm{SO}_{4}$ to form $\mathrm{KAl}_{9} \mathrm{O}_{14}$ and $\mathrm{K}_{2} \mathrm{CrO}_{4}$, respectively. As the temperature increases, more $\mathrm{Al}_{2} \mathrm{O}_{3}$ and $\mathrm{MgO} \cdot \mathrm{Cr}_{2} \mathrm{O}_{3}$ are corroded by $\mathrm{K}_{2} \mathrm{SO}_{4}$, and the reactions of $\mathrm{Al}_{2} \mathrm{O}_{3}$ and $\mathrm{MgO} \cdot \mathrm{Cr}_{2} \mathrm{O}_{3}$ by $\mathrm{K}_{2} \mathrm{SO}_{4}$ are

$$
\begin{gathered}
\mathrm{K}_{2} \mathrm{SO}_{4}+9 \mathrm{Al}_{2} \mathrm{O}_{3}=2 \mathrm{KAl}_{9} \mathrm{O}_{14}+\mathrm{SO}_{3} \\
\mathrm{~K}_{2} \mathrm{SO}_{4}+1 / 2 \mathrm{MgO} \cdot \mathrm{Cr}_{2} \mathrm{O}_{3}+3 / 4 \mathrm{O}_{2}=\mathrm{K}_{2} \mathrm{CrO}_{4}+1 / 2 \mathrm{MgO}+\mathrm{SO}_{3}
\end{gathered}
$$

It can also be seen from the table that the amount of corrosion products in which $\mathrm{MgO}$ or $\mathrm{MgO} \cdot \mathrm{Al}_{2} \mathrm{O}_{3}$ reacted with $\mathrm{K}_{2} \mathrm{SO}_{4}$ is less than $10^{-4}$ mol.

In summary, $\mathrm{Cr}_{2} \mathrm{O}_{3}$ is most susceptible to be corroded by $\mathrm{K}_{2} \mathrm{SO}_{4}$, followed by $\mathrm{Al}_{2} \mathrm{O}_{3}$ and $\mathrm{MgO} \cdot \mathrm{Cr}_{2} \mathrm{O}_{3}$, while $\mathrm{MgO}$ and $\mathrm{MgO} \cdot \mathrm{Al}_{2} \mathrm{O}_{3}$ are the most difficult ones to be corroded by $\mathrm{K}_{2} \mathrm{SO}_{4}$. 
Table 2. Corrosion products and reaction equations of $\mathrm{K}_{2} \mathrm{SO}_{4}$ reacting with the five components of refractory materials.

\begin{tabular}{|c|c|c|c|c|}
\hline \multirow{2}{*}{ Species } & \multicolumn{4}{|c|}{ Temperature $\left({ }^{\circ} \mathrm{C}\right)$} \\
\hline & $600-900$ & 1000 & 1100 & 1200 \\
\hline $\mathrm{Al}_{2} \mathrm{O}_{3}$ & & - & $\begin{array}{c}0.0009 \mathrm{~mol} \\
\mathrm{KAl}_{9} \mathrm{O}_{14} \\
\text { Equation (7) }\end{array}$ & $\begin{array}{c}0.0062 \mathrm{~mol} \\
\mathrm{KAl}_{9} \mathrm{O}_{14} \\
\text { Equation (7) }\end{array}$ \\
\hline $\mathrm{MgO}$ & \multicolumn{4}{|c|}{-} \\
\hline $\mathrm{Cr}_{2} \mathrm{O}_{3}$ & - & $\begin{array}{c}0.0002 \mathrm{~mol} \mathrm{~K}_{2} \mathrm{CrO}_{4} \\
\text { Equation (6) }\end{array}$ & $\begin{array}{c}0.0015 \mathrm{~mol} \mathrm{~K}_{2} \mathrm{CrO}_{4} \\
\text { Equation (6) }\end{array}$ & $\begin{array}{c}0.0076 \mathrm{~mol} \mathrm{~K}_{2} \mathrm{CrO}_{4} \\
\text { Equation (6) }\end{array}$ \\
\hline $\mathrm{MgO} \cdot \mathrm{Cr}_{2} \mathrm{O}_{3}$ & & - & $\begin{array}{c}0.0001 \mathrm{~mol} \mathrm{~K}_{2} \mathrm{CrO}_{4} \\
\text { Equation (8) }\end{array}$ & $\begin{array}{c}0.0008 \mathrm{~mol} \mathrm{~K}_{2} \mathrm{CrO}_{4} \\
\text { Equation (8) }\end{array}$ \\
\hline $\mathrm{MgO} \cdot \mathrm{Al}_{2} \mathrm{O}_{3}$ & \multicolumn{4}{|c|}{-} \\
\hline
\end{tabular}

\subsection{Corrosion Reaction of $\mathrm{KCl}$ and the Five Components of Refractory Materials}

As can be seen from Figure 3, in the range of $600-1200{ }^{\circ} \mathrm{C}$, the tendency of Gibbs free energy change of the five components of refractory materials reacted with $\mathrm{KCl}$ is consistent with the one of the reactions between the five components of refractory material and $\mathrm{K}_{2} \mathrm{CO}_{3}$ or $\mathrm{K}_{2} \mathrm{SO}_{4}$.

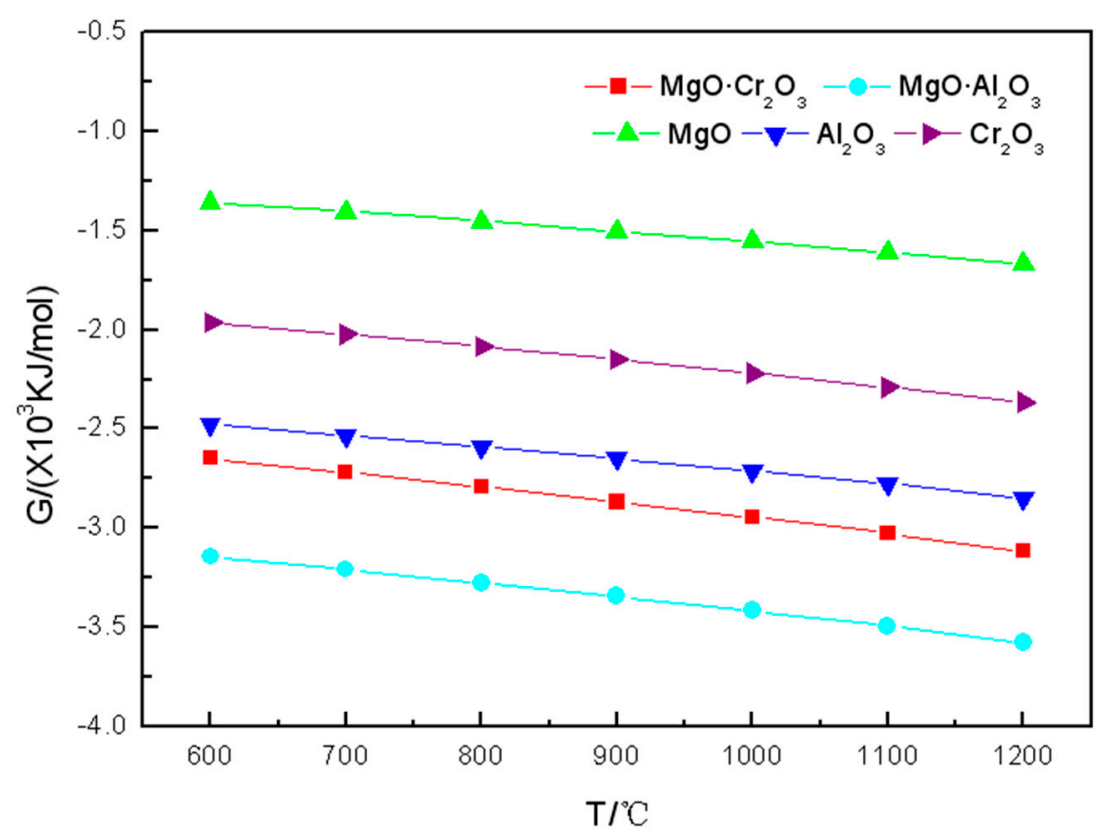

Figure 3. Gibbs free energy of the reaction between $\mathrm{KCl}$ and the five components of refractory materials in the $600-1200{ }^{\circ} \mathrm{C}$ temperature range.

It can be seen from Table 3 that at $600-900{ }^{\circ} \mathrm{C}$, the five components of refractory materials are not corroded by $\mathrm{KCl}$. However, when the temperature further increased to $1000{ }^{\circ} \mathrm{C}$, a small amount of $\mathrm{Al}_{2} \mathrm{O}_{3}(0.0009 \mathrm{~mol})$ and $\mathrm{Cr}_{2} \mathrm{O}_{3}(0.00015 \mathrm{~mol})$ are corroded by $\mathrm{KCl}$ to form $\mathrm{KAl}_{9} \mathrm{O}_{14}$ and $\mathrm{K}_{2} \mathrm{CrO}_{4}$, respectively. The increase in temperature causes more $\mathrm{Al}_{2} \mathrm{O}_{3}$ and $\mathrm{Cr}_{2} \mathrm{O}_{3}$ to be corroded by $\mathrm{KCl}$. The reaction equations are

$$
\begin{aligned}
& 2 \mathrm{KCl}+9 \mathrm{Al}_{2} \mathrm{O}_{3}+1 / 2 \mathrm{O}_{2}=2 \mathrm{KAl}_{9} \mathrm{O}_{14}+\mathrm{Cl}_{2} \\
& 4 \mathrm{KCl}+\mathrm{Cr}_{2} \mathrm{O}_{3}+5 / 2 \mathrm{O}_{2}=2 \mathrm{~K}_{2} \mathrm{CrO}_{4}+2 \mathrm{Cl}_{2}
\end{aligned}
$$


When the temperature rises to $1100{ }^{\circ} \mathrm{C}, 0.00005 \mathrm{~mol}$ of $\mathrm{MgO} \cdot \mathrm{Cr}_{2} \mathrm{O}_{3}$ is corroded by $\mathrm{KCl}$ to form $\mathrm{K}_{2} \mathrm{CrO}_{4}$, and the reaction of $\mathrm{MgO} \cdot \mathrm{Cr}_{2} \mathrm{O}_{3}$ by $\mathrm{KCl}$ is

$$
4 \mathrm{KCl}+\mathrm{MgO} \cdot \mathrm{Cr}_{2} \mathrm{O}_{3}+5 / 2 \mathrm{O}_{2}=2 \mathrm{~K}_{2} \mathrm{CrO}_{4}+\mathrm{MgO}+2 \mathrm{Cl}_{2}
$$

It can also be seen from the table that the amount of corrosion products in which $\mathrm{MgO}$ or $\mathrm{MgO} \cdot \mathrm{Al}_{2} \mathrm{O}_{3}$ reacted with $\mathrm{KCl}$ is less than $10^{-4}$ mol.

In summary, $\mathrm{Al}_{2} \mathrm{O}_{3}$ and $\mathrm{Cr}_{2} \mathrm{O}_{3}$ are most susceptible to corrosion by $\mathrm{KCl}$, followed by $\mathrm{MgO} \cdot \mathrm{Cr}_{2} \mathrm{O}_{3}$, and $\mathrm{MgO}$ and $\mathrm{MgO} \cdot \mathrm{Al}_{2} \mathrm{O}_{3}$ are the most difficult to be corroded by $\mathrm{KCl}$.

It is worth noting that, as can be seen from Figures 1-3, the Gibbs free energy of $\mathrm{MgO} \cdot \mathrm{Al}_{2} \mathrm{O}_{3}$ reacting with the three potassium salts is the smallest. However, it can be seen from the corrosion products calculated from FactSage ${ }^{\mathrm{TM}} 7.0$ that $\mathrm{MgO} \cdot \mathrm{Al}_{2} \mathrm{O}_{3}$ is the least susceptible to potassium salt in the five refractory components except $\mathrm{MgO}$. This also shows that the reaction tendency of the corrosion reaction is the only one that can be obtained by calculating the Gibbs free energy. The estimation of difficulty of the corrosion reaction needs to be obtained by considering the products of Tables 1-3 regarding the corrosion of the refractory component by the potassium salts.

Table 3. Corrosion products and reaction equations of $\mathrm{KCl}$ reacting with the five components of refractory materials.

\begin{tabular}{|c|c|c|c|c|}
\hline \multirow{2}{*}{ Species } & \multicolumn{4}{|c|}{ Temperature $\left({ }^{\circ} \mathrm{C}\right)$} \\
\hline & $600-900$ & 1000 & 1100 & 1200 \\
\hline $\mathrm{Al}_{2} \mathrm{O}_{3}$ & - & $\begin{array}{c}0.0002 \mathrm{~mol} \\
\mathrm{KAl}_{9} \mathrm{O}_{14} \\
\text { Equation (8) }\end{array}$ & $\begin{array}{c}0.0004 \mathrm{~mol} \\
\mathrm{KAl}_{9} \mathrm{O}_{14} \\
\text { Equation (8) }\end{array}$ & $\begin{array}{c}0.0009 \mathrm{~mol} \\
\mathrm{KAl}_{9} \mathrm{O}_{14} \\
\text { Equation (8) }\end{array}$ \\
\hline $\mathrm{MgO}$ & \multicolumn{4}{|c|}{-} \\
\hline $\mathrm{Cr}_{2} \mathrm{O}_{3}$ & - & $\begin{array}{c}0.0003 \mathrm{~mol} \mathrm{~K}_{2} \mathrm{CrO}_{4} \\
\text { Equation (10) }\end{array}$ & $\begin{array}{c}0.0005 \mathrm{~mol} \mathrm{~K}_{2} \mathrm{CrO}_{4} \\
\text { Equation (10) }\end{array}$ & $\begin{array}{c}0.0006 \mathrm{~mol} \mathrm{~K}_{2} \mathrm{CrO}_{4} \\
\text { Equation (10) }\end{array}$ \\
\hline $\mathrm{MgO} \cdot \mathrm{Cr}_{2} \mathrm{O}_{3}$ & & - & $\begin{array}{c}0.0001 \mathrm{~mol} \mathrm{~K}_{2} \mathrm{CrO}_{4} \\
\text { Equation (11) }\end{array}$ & $\begin{array}{c}0.0002 \mathrm{~mol} \mathrm{~K}_{2} \mathrm{CrO}_{4} \\
\text { Equation (11) }\end{array}$ \\
\hline $\mathrm{MgO} \cdot \mathrm{Al}_{2} \mathrm{O}_{3}$ & \multicolumn{4}{|c|}{-} \\
\hline
\end{tabular}

\subsection{Thermodynamic Experiment}

As can be seen from the results calculated by the FactSage ${ }^{\mathrm{TM}} 7.0$ software, $\mathrm{MgO}$ has the best corrosion resistance and is most suitable for refractory materials resistant to potassium salt corrosion. $\mathrm{KCl}$ is the most abundant potassium salt in biomass combustion process, so it is necessary to investigate the thermodynamic experiment of corrosion of $\mathrm{MgO}$ by $\mathrm{KCl}$.

Figure 4 shows the XRD spectra of samples after the test of high temperature corrosion of $\mathrm{KCl}$ and $\mathrm{MgO}$ at three temperatures of 600,1000 , and $1200{ }^{\circ} \mathrm{C}$. As can be seen from the figure, only $\mathrm{MgO}$ and $\mathrm{KCl}$ are detected in the sample at the temperatures of $600{ }^{\circ} \mathrm{C}$ and $1000{ }^{\circ} \mathrm{C}$, and no new substance is formed. Only $\mathrm{MgO}$ is detected in the sample at the temperature of $1200{ }^{\circ} \mathrm{C}$, which is consistent with the results from the modulation by Factsage software. Under the condition of high temperature $1200{ }^{\circ} \mathrm{C}, \mathrm{KCl}$ is in the form of gas. It shows that $\mathrm{MgO}$ has good resistance to $\mathrm{KCl}$ corrosion at $1200{ }^{\circ} \mathrm{C}$, which is consistent with the results calculated by FactSage ${ }^{\mathrm{TM}} 7.0$ software (see Table 3). 


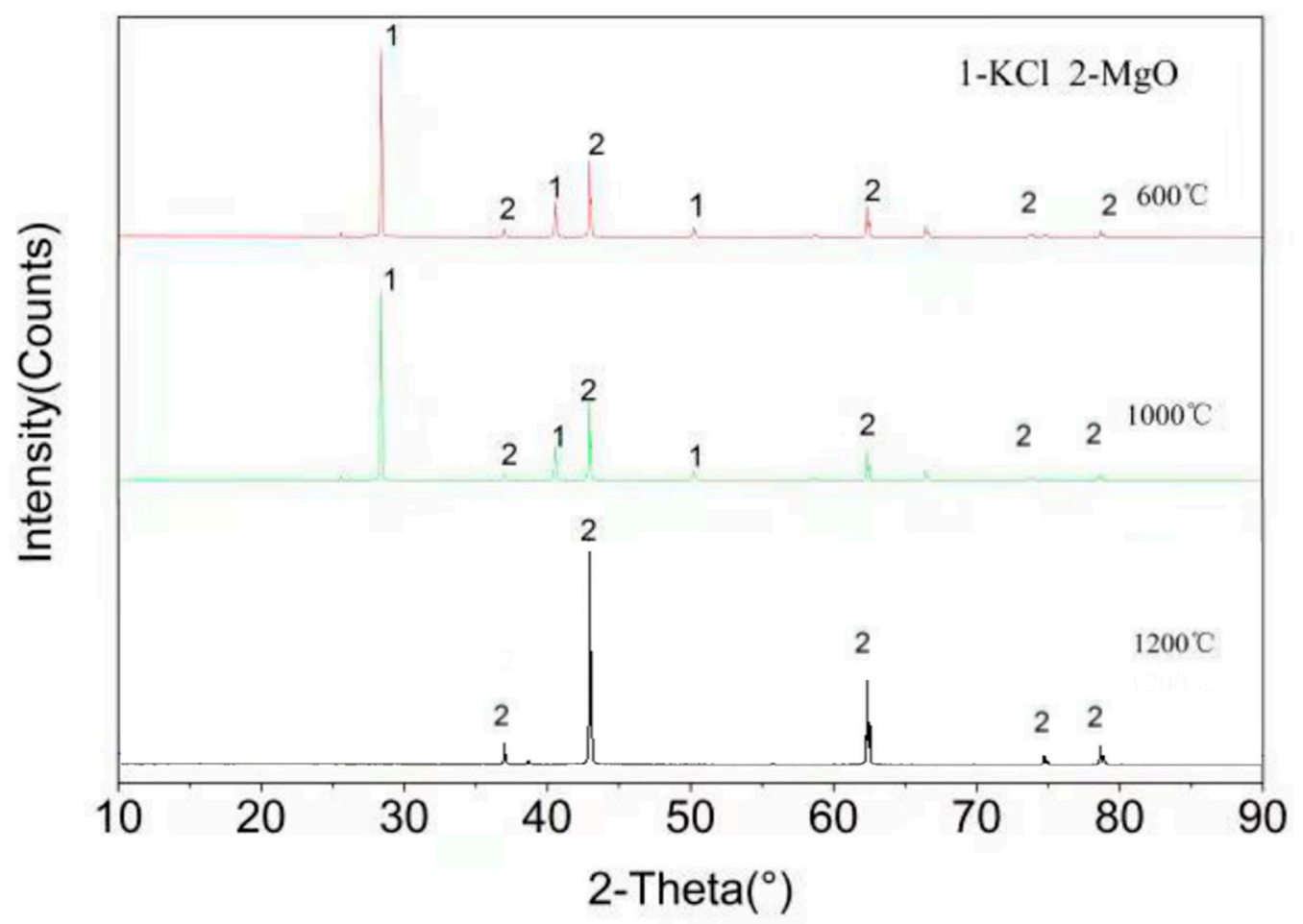

Figure 4. XRD patterns of the products of the reaction between $\mathrm{MgO}$ and $\mathrm{KCl}$.

\section{Conclusions}

From the viewpoint of thermodynamics, this study focused on the Gibbs free energy and the mineral phase of corrosion products of potassium salts corrosion to the five components of refractory materials using thermodynamic calculation method. According to the calculation results, corrosion experiments in the $600-1200{ }^{\circ} \mathrm{C}$ temperature range were carried out.

From the calculation results using FactSage ${ }^{\mathrm{TM}} 7.0$ software, it can be found that the $\mathrm{MgO}$ has the best resistance to the potassium salts corrosion, followed by $\mathrm{MgO} \cdot \mathrm{Al}_{2} \mathrm{O}_{3}$ and $\mathrm{MgO} \cdot \mathrm{Cr}_{2} \mathrm{O}_{3}$, and $\mathrm{Al}_{2} \mathrm{O}_{3}$ and $\mathrm{Cr}_{2} \mathrm{O}_{3}$ have the worst resistance to the potassium salts corrosion. The new phases were $\mathrm{KAlO}_{2}$ and $\mathrm{K}_{2} \mathrm{Al}_{12} \mathrm{O}_{19}$ which appeared as the result of chemical reaction between $\mathrm{Al}_{2} \mathrm{O}_{3}$ and $\mathrm{K}_{2} \mathrm{CO}_{3}$, while $\mathrm{Al}_{2} \mathrm{O}_{3}$ reacts with $\mathrm{K}_{2} \mathrm{CO}_{3}$ or $\mathrm{KCl}$ to form $\mathrm{KAl}_{9} \mathrm{O}_{14} \cdot \mathrm{K}_{2} \mathrm{CrO}_{4}$ was also a new phase in $\mathrm{Cr}_{2} \mathrm{O}_{3}$ or $\mathrm{MgO} \cdot \mathrm{Cr}_{2} \mathrm{O}_{3}$ as the product of the reaction with the three potassium salts. No corrosion products were found in the reaction of $\mathrm{MgO}$ with the three potassium salts. Finally, the results obtained from the FactSage ${ }^{\mathrm{TM}} 7.0$ calculations agrees with XRD analysis. The negative effects of corrosion problems caused by potassium salt can be limited by using refractories contained as much $\mathrm{MgO}$ as possible.

Author Contributions: Conceptualization, Y.Z., G.C., and C.D.; Software, Y.Z.; Validation, Y.Z. and L.L.; Formal Analysis, Y.Z., G.C., and L.L.; Investigation, Y.Z., J.Z. and L.L.; Resources, Y.Z. and C.D.; Data Curation, Y.Z., L.L., and F.L.; Writing-Original Draft Preparation, Y.Z., F.L., and G.C.; Writing-Review and Editing, Y.Z., X.W., and G.C.; Visualization, Y.Z. and G.C.; Supervision, Y.Z. and C.D.; Project Administration, Y.Z. and G.C.; Funding Acquisition, Y.Z. and J.Z.

Funding: This work was financially supported by the Fundamental Research Funds for the Central Universities (2016MS54, 2018ZD08, 2018MS038), National Natural Science Foundation of China (51306054), National Basic Research Program of China (2015CB251501), and State Grid Science and Technology Program (No. SGJN0000ASJS1700136).

Conflicts of Interest: The authors declare no conflicts of interest. 


\section{References}

1. Demirbas, A. Combustion characteristics of different biomass fuels. Prog. Energy Combust. 2004, 30, 219-230. [CrossRef]

2. Demirbas, A. Potential applications of renewable energy sources, biomass combustion problems in boiler power systems and combustion related environmental issues. Prog. Energy Combust. 2005, 31, 171-192. [CrossRef]

3. Arena, U.; Gregorio, F.D.; Santonastasi, M. A techno-economic comparison between two design configurations for a small scale, biomass-to-energy gasification based system. Chem. Eng. J. 2010, 162, 580-590. [CrossRef]

4. Wei, X.; Schnell, U.; Hein, K.R.G. Behaviour of gaseous chlorine and alkali metals during biomass thermal utilization. Fuel 2005, 84, 841-848. [CrossRef]

5. Zhang, B.; Zhong, Z.P.; Xue, Z.Y.; Xue, J.M.; Xu, Y.Y. Release and transformation of potassium in co-combustion of coal and wheat straw in a BFB reactor. Appl. Therm. Eng. 2018, 144, 1010-1016. [CrossRef]

6. Clery, D.S.; Mason, P.E.; Rayner, C.M.; Jones, J.M. The effects of an additive on the release of potassium in biomass combustion. Fuel 2018, 214, 647-655. [CrossRef]

7. Deng, L.; Ye, J.M.; Jin, X.; Che, D.F. Transformation and release of potassium during fixed-bed pyrolysis of biomass. J. Energy Inst. 2018, 91, 630-637. [CrossRef]

8. Mason, P.E.; Darvell, L.I.; Jones, J.M.; Williams, A. Observations on the release of gas-phase potassium during the combustion of single particles of biomass. Fuel 2016, 182, 110-117. [CrossRef]

9. Wang, Y.; Wu, H.; Sárossy, Z.; Dong, C.Q.; Glarborg, P. Release and transformation of chlorine and potassium during pyrolysis of $\mathrm{KCl}$ doped biomass. Fuel 2017, 197, 422-432. [CrossRef]

10. Johansen, J.M.; Jakobsen, J.G.; Frandsen, F.J.; Glarborg, P. Release of K, Cl, and S during pyrolysis and combustion of high-chlorine biomass. Energy Fuel 2011, 25, 4961-4971. [CrossRef]

11. Kassman, H.; Pettersson, J.; Steenari, B.M.; Amand, L.E. Two strategies to reduce gaseous $\mathrm{KCl}$ and chlorine in deposits during biomass combustion- injection of ammonium sulphate and co-combustion with peat. Fuel Process. Technol. 2013, 105, 170-180. [CrossRef]

12. Ma, T.; Fan, C.G.; Hao, L.F.; Li, S.G.; Jensen, P.A.; Song, W.L.; Lin, W.G.; Johansen, K.D. Biomass ash induced agglomeration in fluidized bed. Part 2: Effect of potassium salts in different gas composition. Fuel Process. Technol. 2018, 180, 130-139. [CrossRef]

13. Anicic, B.; Lin, W.G.; Johansen, K.D.; Wu, H. Agglomeration mechanism in biomass fluidized bed combustion-Reaction between potassium carbonate and silica sand. Fuel Process. Technol. 2018, 173, 182-190. [CrossRef]

14. Kuo, J.H.; Lin, C.L.; Wey, M.Y. Effect of alkali concentrations and operating conditions on agglomeration/defluidization behavior during fluidized bed air gasification. Powder Technol. 2011, 214, 443-446. [CrossRef]

15. Niu, Y.Q.; Tan, H.Z.; Hui, S.E. Ash-related issues during biomass combustion: Alkali-induced slagging, silicate melt-induced slagging (ash fusion), agglomeration, corrosion, ash utilization, and related countermeasures. Prog. Energy Combust. 2016, 52, 1-61. [CrossRef]

16. Zhang, H.; Li, J.G.; Yang, X.; Guo, S.; Zhan, H.J.; Zhang, Y.Q.; Fang, Y.T. Influence of coal ash on potassium retention and ash melting characteristics during gasification of corn stalk coke. Bioresour. Technol. 2018, 270, 416-421. [CrossRef] [PubMed]

17. O'Hagan, C.P.; O’Brien, B.J.; Leen, S.B.; Monaghan, R.F.D. A microstructural investigation into the accelerated corrosion of P91 steel during biomass co-firing. Corros. Sci. 2016, 109, 101-114. [CrossRef]

18. Pisa, I.; Lazaroiu, G. Influence of co-combustion of coal/biomass on the corrosion. Fuel Process. Technol. 2012, 104, 356-364. [CrossRef]

19. Antunes, R.A.; Oliveira, M.C.L. Corrosion in biomass combustion: A materials selection analysis and its interaction with corrosion mechanisms and mitigation strategies. Corros. Sci. 2013, 76, 6-26. [CrossRef]

20. Nielsen, H.P.; Frandsen, F.J.; Dam-Johansen, K. Lab-scale investigations of high-temperature corrosion phenomena in straw-fired boilers. Energy Fuel 1999, 13, 1114-1121. [CrossRef] 
21. Reinmöller, M.; Klinger, M.; Thieme, E.; Meyer, B. Analysis and prediction of slag-induced corrosion of chromium oxide-free refractory materials during fusion of coal and biomass ash under simulated gasification conditions. Fuel Process. Technol. 2016, 149, 218-230. [CrossRef]

22. Bale, C.W.; Chartrand, P.; Degterov, S.A.; Eriksson, G.; Gheribi, A.E.; Hack, K.; Jung, I.H.; Kang, Y.B.; Melançon, J.; Pelton, A.D.; et al. FactSage thermochemical software and databases, 2010-2016. Calphad 2016, 54, 35-53. [CrossRef]

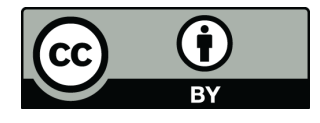

(C) 2018 by the authors. Licensee MDPI, Basel, Switzerland. This article is an open access article distributed under the terms and conditions of the Creative Commons Attribution (CC BY) license (http://creativecommons.org/licenses/by/4.0/). 